\title{
Employee-Driven Innovation in Welfare Services
}

I Thomas Wihlman'

PhD student, School of Health, Care and Social Welfare, Mälardalen University, Sweden

I Magnus Hoppe

PhD, School of Business, Society and Engineering, Mälardalen University, Sweden

\section{Ulla Wihlman}

DrPH, Independent Researcher, Stockholm, Sweden

\section{Hélène Sandmark}

Associate Professor, School of Health, Care and Social Welfare, Mälardalen University, Sweden

\begin{abstract}
There is a growing interest in both employee-driven innovation (EDI) and innovation in welfare services, but a lack of empirical studies addressing innovation from the employee perspective. Accordingly, this study was designed to contribute with well-grounded empirical knowledge, aiming to explore the barriers to and opportunities for participation in innovation experienced by employees of the Swedish welfare services. In order to reach the aim, a qualitative thematic analysis of 27 semi-structured interviews with employees in four municipalities was performed.

The study identified three main themes, with a great impact on the innovative performance of the studied organizations: support, including leadership and innovation processes; development, including creativity and learning; and organizational culture, which includes attitudes and communication, all essential ingredients in EDI. Experienced barriers for innovation were unclear or non-existing innovation processes with ambiguous goals, insufficient learning, and deficient organizational slack, thus creating a tension between day-to-day work and innovation and hindering reflection and exploration.

Attitudes of colleagues and lack of communication were also barriers to implementing innovation, suggesting the need for better management support for a communicative and open culture. Opportunities were found, including commitment to innovation and willingness to try new ideas, but the employees must be given the mandate and sufficient time to develop the potential that emerges from continuous learning, time for reflection, and user dialogue. The conclusion was that incremental innovations existed, but the full potential of these did not benefit the entire organization due to inadequate communication and lack of innovation processes.

The study improves our understanding of how employees regard their involvement in innovation. It also discusses how to make better use of employees' resources in innovation processes and contributes to important knowledge about EDI in the public sector. On the basis of our results, we suggest a model of EDI for use in practice.
\end{abstract}

\section{KEY WORDS}

Employee-driven innovation / innovation / learning / organizational culture / public sector

\footnotetext{
${ }^{1}$ Thomas Wihlman, Department of Psychology, School of Health, Care and Social Welfare, Mälardalen University, Sweden, E-mail: thomas.wihlman@mdh.se
} 


\section{Introduction}

\section{Public sector innovation}

M

ost chief executives today regard innovation as a key imperative; in the context of the public sector, it may even be a core process (Mulgan, 2007). Public sector innovation has come into focus as the sector faces challenges stemming from changing citizen demands, financial conditions, and huge social sector tasks involving what are sometimes called "wicked problems" due to their high complexity and involvement of many stakeholders with conflicting interests (Rittel and Webber, 1973; Bason, 2010). In this respect, the public sector can also be seen as a complex system, demanding a broad approach to innovation involving many stakeholders (Jalonen, 2011). The public sector constitutes a large part of the total economy in many countries, and a wellfunctioning public sector is essential for the development of the industry and service sectors. Public sector innovation is therefore high on the agendas of many governments.

The approaches of Western governments to public sector innovation vary considerably, even so in the Nordic countries. The Danish government has stated that it intends to become a leader in public service innovation (Danish Government, 2006). Mindlab (2012) is a Danish cross-ministerial unit, working with the public sector to help decision-makers and employees view their efforts from the outside in, that is, from the citizen's perspective. The Danish Confederation of Trade Unions has also been a forerunner in employee-driven innovation (EDI) by using the EDI concept and publishing reports in the field (Danske LO [Danish Confederation of Trade Unions], 2008). In Finland, Tekes, a government agency, is responsible not only for innovation but also for working conditions in both the private and public sectors (Alasoini, 2011). Tekes has also started the Liideri program with the goal of making Finland's workplaces Europe's best by 2020 . One of its main goals is to use the knowledge and ideas of employees in innovation and development (Arbets-och näringsministeriet [Ministry of Employment and Economy], 2013). In Norway, Forskningsrådet (The Norwegian Research Council) (2012) recently published its policy for public sector innovation. The Norwegian government in its innovation policy is stressing employee participation and this is done in cooperation with the Norwegian Confederation of Trade Unions and NHO, the Norwegian organization for employers (Nærings-og handelsdepartementet [Ministry of Business and Trade], 2008).

The diversity is similar outside the Nordic countries. In the UK, besides government efforts, we find the government-funded but independent charity Nesta and the Innovation Unit, a nonprofit organization working on innovation in local government, public healthcare, and so on (Nesta \& Innovation Unit, 2012). In Australia, the government introduced the Australian Public Service Innovation Action Plan in 2009 (Australian Government, 2009), focusing on building innovation capacity, developing innovation consciousness, supporting cocreation, and educating leaders.

Sweden, however, has not been a leader in public sector innovation, including EDI. It is only in the past decade that we have seen government policy documents in Sweden concerned with public sector innovation (Socialdepartementet [Ministry of Health and Social Affairs], 2011; Government Offices of Sweden, 2012). The focus, however, has been on public procurement and on improving public service provision processes, not on EDI. The OECD is also describing Swedish innovation policy, as weak (OECD, 2013), stressing the need for a better conceptual and empirical basis for measuring and promoting public 
sector innovation and that Sweden's innovations policy should be broadened to ensure coverage of public sector innovation.

\section{Employee-driven innovation}

As the public sector and its welfare services are highly dependent on their workforce, employees can also be seen as important drivers of innovation (Hovlin et al., 2011). EDI is a big challenge, a process with numerous opportunities but not without barriers to progress. It can be seen as a bottom-up activity, usually occurring outside formal job descriptions and taking time from what employees are officially paid to do (Birkinshaw \& Duke, 2013).

Research interest in EDI has often been theoretical in nature, discussing what factors are favorable for EDI (Smith et al., 2012). This research interest has also encompassed the public sector. From a Nordic perspective, the Nordic Council of Ministers notes that the culture of the Nordic countries strengthens EDI, because Nordic workers are characterized by professionalism, adaptability, independence, and responsibility and because of the associated leadership culture (Fogelberg Eriksson et al., 2013, p. 8).

It should be noted that Sweden, where this study took place, has a large public sector compared with most other European countries, amounting to $20 \%$ of the GNP (Government Offices of Sweden, 2012). Local governments are responsible for core services such as healthcare, primary and secondary education, eldercare, and childcare. Counties and municipalities also have the right to levy taxes.

New public management (NPM) has changed the public sector in many countries and may itself be described as an innovation. It has also been described as a "trend toward individualization in an explosion of management" (Almqvist, 2006, p. 14). In the education and eldercare sectors, Sweden has largely deregulated and opened up to private providers, more so than in other Nordic countries (Regeringen [Government of Sweden], 1993). Despite these changes, Swedish public opinion seems to hold that the Swedish public sector is less innovative than is industry (IVA \& Sifo, 2010). However, international analysis, comparisons (Eurobarometer, 2012), and research (Earl, 2002; Bekkers et al., 2011) suggest that the public sector is just as innovative as the private sector in Sweden.

NPM has also made the public sector more complex and increasingly akin to the service sector. The effects of this transition have been widely discussed (Christensen \& Lægreid, 2007; Hasselbladh et al., 2008; Hartman, 2011). Hartman found that, despite increased competition and changes in organization and governance, no general conclusions about improvements in quality, efficiency, innovation, and costs could be drawn.

It is important to study how employees' resources, such as ideas, creativity, competence, and problem-solving abilities, are addressed in EDI. Much of public sector innovation applies a top-down approach, but the necessity of a bottom-up approach is increasingly understood, as the "bottom" is where the client actually meets the public sector (Smith et al., 2012). In Sweden, where much of the public sector is local, this may be especially important. Accordingly, this study explores the barriers to and opportunities for participation in innovation experienced by employees of the Swedish welfare services.

It should also be noted that public sector is something else than the private sector, why it is difficult to directly transfer concepts, theory, and empirical findings from 
private firms to public service, thus there is need for both empirical findings and theory development (Hartley, 2005; Langergaard and Hansen, 2013).

\section{Aim of study}

Aiming to explore the barriers to and opportunities for participation in innovation experienced by employees of the Swedish welfare services, this study was designed to contribute with well-grounded empirical knowledge.

\section{Conceptual framework}

For this study, we define innovation as "the intentional introduction and application within a role, group or organization of ideas, processes, products or procedures, new to the relevant unit of adoption, designed to significantly benefit the individual, the group, the organization or wider society" (West \& Farr, 1990, p.9). An innovation might be either radical or incremental. Radical innovation is the innovation that creates fundamental changes in activities and behavior in an organization or branch (Meyer \& Allen, 1991). Many radical innovations diminish the worth of previous knowledge. Incremental innovation, in contrast, can be described as innovation building on existing knowledge and resources (Davila et al., 2005).

Klitmøller et al. (2007) define EDI as the development and implementation of new organizational forms, service concepts, modes of operation, and service processes in which the ideas, knowledge, time, and creativity of employees are actively used. Kesting and Ulhøi (2010) add the proviso that the employee should not be assigned to this task, and restrict EDI to radical innovation. In our view, this restriction is unnecessary, as incremental EDI can be useful and may also lead to radical innovation. Accordingly, for our purposes, we use the Klitmøller et al. (ibid) definition of EDI.

Public sector employees are in close contact with customers and users and may be at the center of information flow in the organization, which makes them important sources of innovative ideas (Klitmøller et al., 2007). Kesting and Ulhøi (2010) note that employees have exclusive procedural information about processes and have outside relationships, for example, with clients and colleagues, both of which greatly benefit innovation. The impact of this information and knowledge can be huge: "Although each individual may only be able to develop limited, incremental innovations, the sum of these efforts can have far-reaching impacts" (Tidd \& Bressant, 2009, p. 115). This also supports the view that EDI should not be limited to either incremental or radical innovation.

As research into EDI is still in its infancy, we lack well-established knowledge about its antecedents. Smith et al. (2012) have proposed that the most relevant factors promoting EDI are management support, autonomy, collaboration, and organizational norms favoring exploration (that is, an organizational climate allowing exploration). Birkinshaw and Duke (2013) describe four categories of EDI enablers: time out (to give employees time for creative thought), expansive roles (moving beyond the confines of the assigned job), competition, and open forums. The importance of time, that is, organizational slack allowing room for innovation, is stressed in a Swedish study of public sector innovation (Hovlin et al., 2011). 
In addition, it should be noted that Sweden has a special act dealing with worker participation in decisions, Medbestämmandelagen (Law on workers' participation in decisions) (Regeringen [Government Offices of Sweden], 1976), which regulates decision-making in all sectors. Swedish managers are known for acting in nonauthoritarian ways, and the hierarchical distance between management and employees is minimal (Lämsa, 2010). This is something that could be advantageous for EDI, relating to the aforementioned antecedents described by Smith et al. (2012). Nordic leadership styles are generally considered employee oriented (Lindell \& Arvonen, 1996) and the use of human resources is also seen as bolstering innovation (Eurobarometer, 2011). This may also be seen in the Fourth survey of working conditions (Parent-Thirion et al., 2007) in which the Nordic countries generally are way ahead regarding the possibilities both for learning and employee opportunities to put forward own ideas, as compared with the EU average. However, differences have been found in earlier research between Sweden and the other Nordic countries, where the Swedish employees are more willing to adhere to formal rules than their neighbors (Smith et al., 2003).

\section{Complexity of the public sector}

The public sector differs from the private sector in many respects, making for a highly complex organizational milieu. This complexity can be described as stemming from the sector's many stakeholders, inadequate resources (not easily expandable), and high transparency requirements. This complexity is also reflected in the managerial role that largely must balance conflicting goals (Nyström, 2010). Further complexity arises when former monopolies are broken up, and management must gain knowledge of and act in a competitive market (Kallstenius, 2010).

This complexity leads us to view the public service organization as a complex responsive system in which developments and ideas evolve via communication processes, the individual continually affecting the organization and vice versa (Stacey, 2003). These processes generate the ideas that lead to innovation (Fonseca, 2004). This also means that management control can no longer be of a traditional hierarchical, top-down sort. Autonomy in one's work tasks is a critical factor for individual wellbeing (Karasek \& Theorell, 1990). It has also been demonstrated that participation in innovation can foster autonomy (Rasulzada, 2007) and alleviate the negative effects of work demands, enhancing control of one's work (King et al., 2007).

In addition, it has also been demonstrated that learning strategies in jobs involving high control or high problem-solving demands can help promote innovation, because these jobs in themselves stimulate learning (Holman et al., 2012). One such job is care of the elderly, in which the employees have to handle many different situations and demands. The employees' learning orientation and transformational leadership are also positively related to creativity (Chang et al., 2011), leading to new ideas and eventually innovation. This does not mean that the employees do not need to learn the rules and routines, as Ellström has stressed (Ellström, 2005). Ellström points to the importance of learning as the foundation for innovation, both in the context of the production logic, that is, learning routines and processes, and in the context of the development logic, that is, learning for development in the innovative organization. Furthermore, Ellström (2010, p. 27) emphasizes the importance of practice-based innovation, "a cyclical 
process of adaptive and developmental learning driven by contradictions and tensions between explicit and implicit dimensions of work processes." Adaptive learning of routines and processes may also lead to mastering of the work processes, mastering giving time to developmental learning (Høyrup, 2012). In addition, we can note that improvisation, according to Miner (2001), can be viewed as the link between learning and innovation. Thus, learning plays a key role in EDI.

In complex organizations, as found in public sector welfare services, fostering employee autonomy (Smith et al., 2012) and control (King et al., 2007) is important for EDI. Kristiansen and Bloch-Poulsen (2010) suggest three important criteria for EDI leading to the implementation of a new work routine. The routine must create value for the organization, it must improve work organization, and it must improve working life quality for employees. However, as we see it, the effects of an innovation, such as improved working life quality, cannot be measured in its initiation phase.

That is not to say that well-functioning processes are not important for the implementation of innovation. Indeed, they are. Accordingly, another part of our conceptual framework is the innovation process. In this process, the initiation phase consists of information gathering, conceptualization of all events, and planning for the adoption of an innovation, finally leading to the decision to adopt, while implementation consists of all the events, actions, and decisions involved in putting the innovation to use. The $d e-$ cision to adopt the innovation is the dividing line between the initiation and implementation phases (Rogers, 2003). However, the innovation process as we see it does not have to be sequential; instead, it may be seen as a flow of communication and action, more like the complex responsive processes described by Stacey (2003). For the organizational culture to influence creativity and innovation, strategy, support mechanisms, structure, behavior, and communication are especially prominent (Martins \& Terblanche, 2003).

\section{Methods}

\section{Research design and data collection}

This article presents a qualitative study of Swedish welfare services, performed in eight welfare service units in four of Sweden's 290 municipalities in 21 counties. A qualitative research design was used to obtain a deeper understanding of the experiences and views of employees. Semi-structured interviews were used to establish a dialogue with the employees, as is suitable when studying complex issues (Kvale \& Brinkmann, 2009). A thematic analysis was conducted to achieve the research aim (Braun \& Clarke, 2006).

We strove to make a strategic selection of units covering major aspects of the welfare services, such as education and social services. In Sweden, preschools and daycare centers are part of the education system. Five of the units were on the provider side of the purchaser-provider relationship and three belonged to a traditional municipal organization outside this division, so different organizational forms were examined.

Our dataset contains interviews with a total of 27 employees (Tab. 1). To ensure that the interviewees understood the meaning of innovation, they were asked about their understanding of the concept. If they were in doubt, an explanation was given according to the definitions mentioned earlier in this article. The focus of the interviews was on what could be accomplished in a single service unit, not in the organization as a whole. 
An interview guide was developed and provided the basis for the semi-structured interviews. The main areas covered in the guide were the attitudes and actions of the interviewees' coworkers and manager as well as the interviewees' participation in innovation, sense of responsibility for and influence on change and development, general experiences of change, influence, access to information, learning, and professional development, and dialogue with users or customers.

Table II Overview of Units and Informants

\begin{tabular}{|c|c|c|c|c|c|}
\hline \multirow{2}{*}{$\frac{\text { Unit }}{1}$} & \multirow{2}{*}{$\begin{array}{l}\text { Unit name } \\
\text { Short-term care for elderly }\end{array}$} & \multicolumn{4}{|c|}{ Professions/occupations } \\
\hline & & $\begin{array}{l}\text { Two assistant } \\
\text { nurses }\end{array}$ & $\begin{array}{l}\text { One activity } \\
\text { leader }\end{array}$ & $\begin{array}{l}\text { One physio- } \\
\text { therapist }\end{array}$ & $\begin{array}{l}\text { One techni- } \\
\text { cal assistant }\end{array}$ \\
\hline 2 & Palliative care & $\begin{array}{l}\text { Two assistant } \\
\text { nurses }\end{array}$ & & & \\
\hline 3 & Daycare center & $\begin{array}{l}\text { Two preschool } \\
\text { teachers }\end{array}$ & $\begin{array}{l}\text { Two } \\
\text { child-care } \\
\text { workers }\end{array}$ & $\begin{array}{l}\text { One youth } \\
\text { worker }\end{array}$ & \\
\hline 4 & Nutrition/restaurant & Four cooks & & & \\
\hline 5 & Street and park maintenance & Two gardeners & $\begin{array}{l}\text { Two park } \\
\text { workers }\end{array}$ & $\begin{array}{l}\text { One techni- } \\
\text { cal assistant }\end{array}$ & \\
\hline 6 & Refugee center & One assistant & $\begin{array}{l}\text { One social } \\
\text { worker }\end{array}$ & & \\
\hline 7 & Social worker (youth) & $\begin{array}{l}\text { Two social } \\
\text { workers }\end{array}$ & & & \\
\hline 8 & $\begin{array}{l}\text { Recruitment center (short- } \\
\text { term substitutes) }\end{array}$ & $\begin{array}{l}\text { Two recruit- } \\
\text { ment officers }\end{array}$ & & & \\
\hline
\end{tabular}

The units had 10 to 55 employees. A manager who reported to the district manager or the like led each unit. The researchers asked the managers to select interviewees of varying experience levels and ages, and this was done.

A meeting was held with three of the managers, presenting the background of the study, and all managers were given written information. Managers informed their employees about the study.

All interviews were audio recorded and transcribed verbatim. The interviews were performed from April 2011 to June 2012. One interview was performed simultaneously with two employees because of the work situation. Saturation was achieved when 27 interviews had been completed, as no novel information was then being added from the additional material. Interviews were held in a quiet, comfortable environment by the first author and lasted 35 to 65 minutes, with an average duration of approximately 50 minutes.

Women formed a large majority of the interviewees (22 of 27), which mirrors their representation in the selected units. The interviewees' educational level varied and ages ranged from 28 to 60 years. Two participants had dual tasks, as head or assistant deputy head in parallel with their work in the unit; as they only had part-time managerial responsibility and no financial responsibility for personnel, these interviewees were included in the employee category. 


\section{Data analysis}

We conducted a thematic analysis via an iterative process of alternating between the raw data and the preliminary themes (Braun \& Clarke, 2006). MAXQDA qualitative data analysis software (Maxqda, 2013) was used to facilitate the analysis (Lewins \& Silver, 2006).

After transcription, the interviews were read thoroughly to gain an impression of the interviews as a whole. In a second reading, meaning units, what Braun and Clarke (2006) describe as interesting features of the data, were highlighted; that is, significant parts of sentences, whole sentences, and parts of paragraphs judged to have a bearing on the research questions were identified. The meaning units were each assigned a code; a particular code can appear in several documents that contain similar meaning units.

After the preliminary coding, we analyzed the meaning units and coding in a greater depth to find the latent content. This was done iteratively to identify themes or patterns, following Braun and Clarke (2006). Some condensed meaning units were reclassified, while others were reassigned a different code. Depending on their similarities and differences, the codes were grouped into three main themes as a result of the iterative process; this included going back and forth among meaning units, codes, and themes to finally decide on the theme structure. This was done in consultation with the third author (UW) until sufficient agreement was reached. Quotations are used to illustrate each theme and its connection to the original data and to enhance trustworthiness.

\section{Methodological considerations}

A particular strength of the study is that it gives voice to a group seldom talked about in innovation studies, namely, the employees. As the study took place in municipalities organized in various ways and in units from major parts of the welfare services, the empirical material encompassed a considerable range of variation. Accordingly, the results might be applicable to similar settings in other Swedish municipalities.

To avoid bias and enhance trustworthiness in interpretation, inter-subjective agreements were employed in the analysis, as the emerging themes were continuously discussed among the coauthors. To enhance credibility, following Guba (1981), we have described the research process thoroughly, including the selection of informants.

Interviews by themselves entail methodological difficulties; one being that the informants in a study of this sort may try to satisfy the interviewer (Alvesson, 2003). The interviewer in this study counteracted this tendency by reframing, repeating, and expanding the questions as described by May (1991).

\section{Ethical considerations}

The study followed the recommendations of Vetenskapsrådet (Swedish Research Council) (2012) for studies in the humanities and social sciences. Every informant was informed about the study, both orally and in writing, including an explanation of how the results would be used; they were also informed that the confidentiality of individual answers would be safeguarded and that each person had the right to cancel participation at any time. This information was given by the managers some weeks before the 
interviews took place and repeated just before the researcher started each interview. Before the interviews started, each participant also signed a written consent statement containing this information. To safeguard confidentiality, each quotation is assigned a code in lieu of the informant's name.

\section{Results}

The study indicates that there were several barriers to employee participation in innovation, but also that there were opportunities for this as well. Three main themes were identified in the analysis: (1) development, (2) support, and (3) organizational culture. The themes also included subthemes. Table 2 presents an overview of the themes and subthemes, with a quotation for each main theme to illustrate the relationship to the original data. The themes overlap each other and are interrelated.

Table II Overview of the themes and subthemes

\begin{tabular}{|c|c|c|}
\hline Main themes & Subthemes & Illustrative quotations \\
\hline I. Development & $\begin{array}{l}\text { - Learning processes } \\
\text { - Creativity processes }\end{array}$ & $\begin{array}{l}\text { We have all agreed that we want to be professional. } \\
\text { For instance, we do not want to judge someone } \\
\text { with some kind of illness for what they have actually } \\
\text { done. Instead, we try to understand what in their } \\
\text { situation caused them to do this. }\end{array}$ \\
\hline 2. Support & $\begin{array}{l}\text { - Innovation processes } \\
\text { - Leadership }\end{array}$ & $\begin{array}{l}\text { The economics are limiting. I have ideas that I think } \\
\text { would be very effective, but they cannot be imple- } \\
\text { mented. Another limit is the type of organization } \\
\text { we have, because every unit has its own budget and } \\
\text { does not receive money for cooperation. }\end{array}$ \\
\hline 3. Organizational culture & $\begin{array}{l}\text { - Attitudes } \\
\text { - Communication }\end{array}$ & $\begin{array}{l}\text { That was the first thing that struck me when I } \\
\text { started here. At the other place, we worked as a } \\
\text { team. We were encouraged a lot more to come up } \\
\text { with ideas... you could make changes and they did } \\
\text { not have to cost so much. }\end{array}$ \\
\hline
\end{tabular}

\section{Development}

The conditions for learning and creativity were seen as important for the development of ideas leading to innovation. Thus, two subthemes were identified: Learning processes and creativity processes.

\section{Learning processes}

Informants mentioned learning as something that stimulated them to innovate. They described courses they had taken, often out of their own interest or initiated by new 
work demands. According to the informants, management encouraged learning, and they cited specific examples of courses attended. In some cases, the initiative to attend courses came from the employee, in other cases from the manager. Interviewees also occasionally mentioned that their interest had been stimulated by a lecture.

The informants described how, at unit meetings, they had been called upon to describe what they had learned at courses and how it could be applied at work. Formal courses were emphasized, while other forms of learning were hardly mentioned. Employees were sometimes asked by the management to attend courses or seminars: "Yes, I've taken part in courses and we share knowledge with each other. It's learning. You get a lot of learning here if courses are available, but there are courses that could be better" (I22).

Some informants admitted that they never advanced their specific proposals for learning or education because they did not feel the need for it.

No informant talked about strategy, organizational goals, learning at the workplace (e.g., practice-based learning), or the link between learning and new ideas and innovation.

\section{Creativity processes}

Most informants saw themselves as creative persons, solving problems in new situations arising from the complexity of their work. They also indicated a high level of freedom and autonomy in solving these problems. Organized meetings were held in various forms: either in smaller groups, such as team meetings, or in meetings of the unit as a whole. Meetings were used to discuss ideas on which an employee wanted feedback from colleagues. This sometimes happened after an individual's idea was raised and recognized during a coffee break or in a small formal group. Examples of both informal and formal processes were cited:

"The refreshment room is a useful place for a discussion, but if I'm not happy with it, I raise the question at staff meetings or in a routine meeting. Sometimes you can get an idea, but then you have to get other people's points of view (I1)."

One of the units mentioned their one or two-day planning meetings, at which time was made for discussion of how to achieve the goals set. There were also complaints about some meetings, such as groups that were too big or in which the same people talked at every meeting. This kind of organizational culture was a barrier that prevented some less assertive employees from raising their voices and presenting their ideas. Some informants stated that they had helped the newly recruited staff propose their ideas. Others mentioned that experience of the workplace was needed if one wanted to propose ideas that could lead to an innovation.

Contacts with colleagues in other units were limited. One profession had an active Facebook group. Another profession used to hold regular meetings with colleagues elsewhere in the municipality, but these meetings were not being held at the time of the study because of reorganization.

Time was said to be an obstacle to discuss ideas. However, the situation varied among the units and was also a matter of attitude. One informant described it as a matter of priorities: "You could always find a minute, it would save time if you worked together." (I7) 


\section{Support}

This theme relates to how ideas for innovation were dealt with, including the kind of support employees received from management and how management generally acted in response to innovation issues. The subthemes were innovation processes and leadership.

\section{Innovation processes}

Neither specific goals nor problems where innovation could be useful were mentioned; instead, implementation decisions were made ad hoc. Informants were unaware of any innovation processes involving resources such as having a facilitator knowledgeable about innovation processes to talk to or offer advice. When it came to implementation, however, some informants were optimistic about the possibilities of getting help if they actually came up with a great idea: "Yes, I absolutely think so, that you would get help if needed" (I25).

Customers or clients (the word choice varied) sometimes seemed to be patronized by some informants. The customers were described as not understanding their own needs or the needs of their elderly parents, children, and so on, though they were seen as influencing the organization. Informants described how surveys were used in relation to innovation and change. They did not describe this as a formal or informal open innovation process, although when asked, admitted that surveys could be seen as identifying ideas for improvement, this being the first step of an innovation process.

Time was more of a problem than was limited funding. Staff at one unit had a particular difficulty finding time for dialogue; this hampered participation, the creative process, and implementation, even though funding may have been available.

Some statements, such as "we test ideas," "we can change," and "we dare to take risks," indicated opportunities to test and develop ideas, so the risk-taking associated with new, untested ideas, was not seen as a barrier.

\section{Leadership}

According to their subordinates, managers understood the necessity of innovation and expressed support for it; they were said to listen and be encouraging during the daily work and in the various meetings. What this led to from an innovation process point of view was unclear. In addition, when an idea was accepted, its implementation might be left to the person who proposed it, who presumably was supposed to act and to engage colleagues: "You must be the driving force yourself; find opportunities and give time to each other" (I14).

Diversity within units led to situations in which the manager did not have all the necessary skills to judge the ideas put forward. Although informants expressed a positive attitude toward innovation, a problem often mentioned was that management demanded too much change and initiated the implementation of too many new ideas. This led to some not yet completed projects being abandoned for other new ideas: "A manager must know when it's time to slow down on a project, so that one is not out on a winter road with smooth summer tires" (I8). 


\section{Organizational culture}

The informants mentioned a lack of communication between employees as a problem. This problem was linked to the fact that employees were a driving force for participation in innovation. Both subthemes, that is, employees' attitudes and communication among employees, were important for innovation.

\section{Employees' attitudes}

The innovation concept was known to most of the interviewees, but the interpretation varied. Some informants used the word "innovation," while others spoke about using related terms such as "change." In most cases, innovation was seen as constituting a fairly substantial change in the work process. The informants often spoke about their dedication to change and to innovation: "I associate innovation directly with always trying new ideas, that it's a way for us to work; the direction for every cook should be to innovate, renew, and improve continuously" (I8).

Informants described situations that made many demands on them yet offered little autonomous control of the work tasks, which led to fatiguing. These pressures and the effects of earlier cutbacks were mentioned as adversely affecting innovation, as staff shortages led to limited time available for communicating new ideas. Another negative effect on innovation arose when employees developed ideas that could benefit their clients, but simultaneously realized that these ideas conflicted with the rigid requirements of purchasers or political stakeholders, reducing the likelihood of advocating the ideas internally.

\section{Communication}

Informants also touched on their colleagues' attitudes toward innovation. Most informants described colleagues as positive toward testing new ideas, entering into a dialogue, and the like. However, there were also frequent complaints about the backwardness of certain colleagues, about people resisting change, and so on, highlighting differences in thinking and internal conflicts as significant barriers to innovation. Informants also mentioned that the work situation could be very demanding, and that it was no use wasting time on colleagues who were negative: "Yes, there is a built-in pattern of thinking and it feels comfortable and secure, then you do not have to work so much on your own approach. I experience this as resistance" (I27).

Some informants who had been at the same workplace for many years admitted that, as they could not see the workplace with fresh eyes, they welcomed new employees and fresh views. However, they also pointed out that theirs was a difficult business that took time to learn, so one could not expect any good ideas from newcomers.

New employees had very positive attitudes and clearly stated that they wanted to make an impression. Their older colleagues complained about ideas they had expressed earlier but had never been given the opportunity to realize. Older colleagues also expressed a fear that this would most likely happen to all newcomers. 


\section{Discussion}

Our study identifies several factors as especially important for EDI in welfare services, namely a conducive organizational culture, development, and support. The study indicates that highly committed and competent employees can be a very positive and vital force in helping the public sector face the challenges confronting it. The model shown in Fig. 1 includes the core elements of EDI in this context, constituting a roadmap for creating better EDI in welfare services. We propose that practitioners should scrutinize their own organizations, building on and reinforcing their strengths and addressing their weaknesses. In our discussion, we touch on the components of the model, cite related research, and make some general suggestions for improvements on the basis of this study. We start by discussing our model in relation to other general findings regarding EDI.

Smith et al. (2012) identified the antecedents of EDI as leadership support, autonomy, collaboration, and organizational norms favoring exploration. Our model incorporates these factors, but notably adds structures such as the innovation process as well as a greater focus on development, including learning and creativity. The EDI enablers suggested by Birkinshaw and Duke (2013), that is, time out, expansive roles, competition, and open forums, are interesting but limited in scope. As we see innovation as more of a collective effort rather than based on the individual's ideas, team-based competition may be a way forward. Finally, Klitmøller et al.'s (2007) definition of EDI identifies its core elements, that is, ideas, knowledge, time, and creativity, all of which are parts of our model. However, as our objective has not been to define EDI, but instead to make the concept practical and useful, our model also incorporates the particular features encountered in our study, such as the importance of having an organizational culture in which good communication and dialogue are central.

\section{Development: Learning and creativity}

As mentioned, learning is a vital factor in EDI, especially given the complexity of public service organizations. Brandi and Hasse (2012) suggest that EDI is valuable as a bottom-up process, based on the experiences of employees as to what they experience as problems, not what is defined by top management as a problem. Nilsen et al. (2012) understand learning in this context as something based on the experiences, knowledge, and skills of employees. We also find it useful to uphold Ellströms' (Ellström, 2005) distinction between learning about procedures and developmental learning, the latter having a stronger direct connection to innovation. Complex responsive processes of organizations involve a steady ongoing exchange between the individuals who form the organization and in turn are formed by it (Stacey, 2003). We view this ongoing reciprocal formation as a continuous learning process and as the basis for creating ideas that will eventually lead to innovation. Evans et al. (2006) find that participation, reflection, recognition, and teamwork are important factors embedded in the organization that creates the preconditions for learning.

This view, however, does not go unchallenged. Kesting and Ulhøi (2010) see the origin of radical innovation in changing routines and procedures. We argue that flexibility is important for welfare service employees. Every day, employees confront different situations and different user demands. Fixed routines and procedures are less important, 
Figure I: Employment commitment in 16 European countries in 2005-2007 (means).

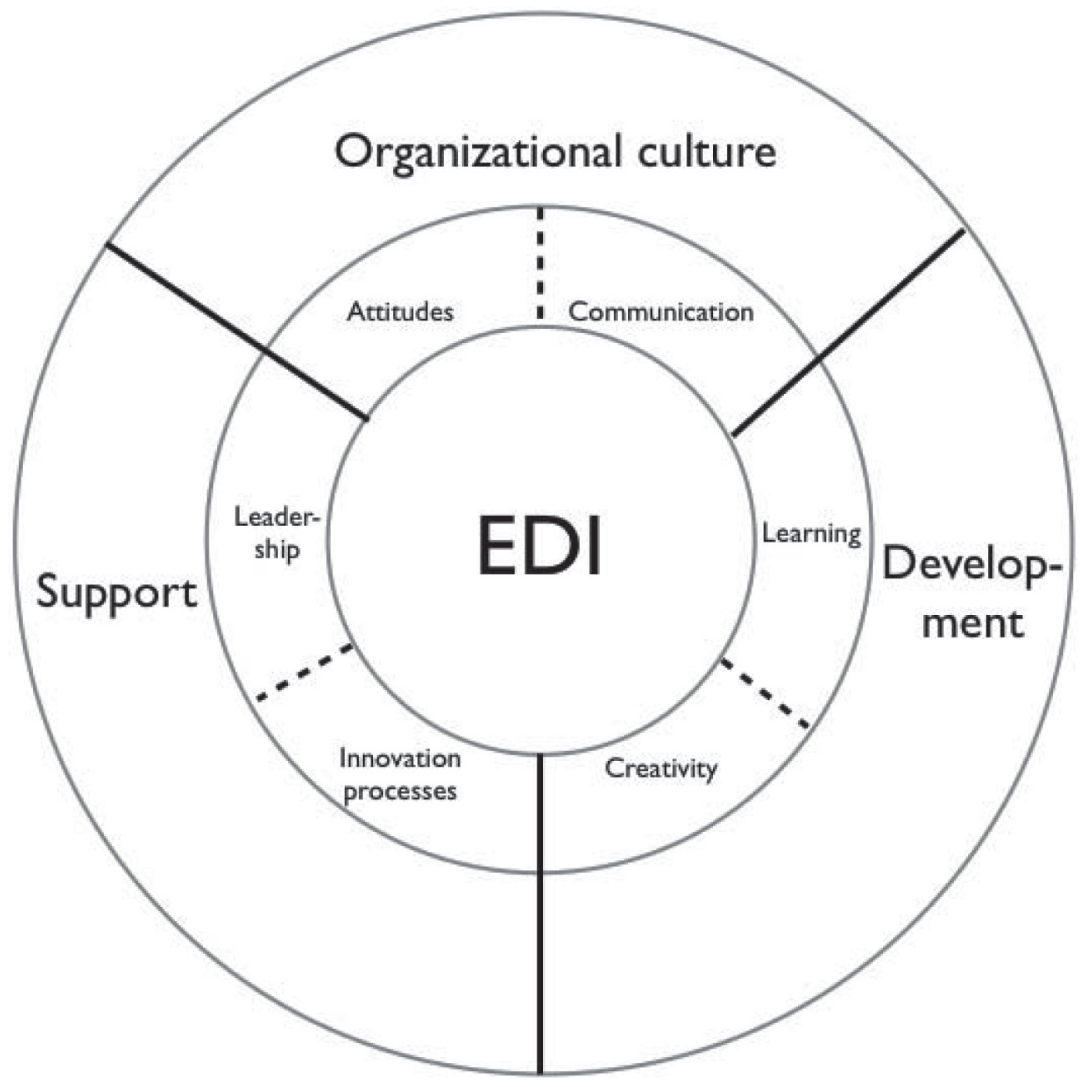

as the situation is constantly changing and evolving. There may even be a problem with best practices and well-proven experiences, as relationships and situations are highly complex and not easily comparable. We agree with Nilsen et al. (2012) that it is important for future research to study how learning and creativity can be reinforced in the public sector and used for development and innovation.

Colleagues are influential when it comes to possibilities for idea development and innovation. Their influence is both informal and formal and their importance may differ depending on the interviewee's status and the actual position in the organization. A possible explanation for the negative reactions to ideas from colleagues is the tight staffing situation. To avoid stress, a common strategy for employees is to focus on their immediate work, rather than on discussing new ideas and innovation. There are also other explanations, such as the employee's hierarchical position. The organizational position of the nursing assistant group studied by Åmo (2006) is similar to that of the employees studied here. Åmo finds that in low-hierarchy jobs, such as nursing assistants, colleagues are the most important factor influencing the attitude to innovation, while physicians and nurses are more affected by information from management (ibid). 


\section{Organizational culture: Communication and attitudes}

As limited time was experienced as a constraining factor in our study, including lack of time for discussion and reflection, communication was not facilitated. Organizational slack, as Rogers (2003) points out, is important for creativity and innovation, though too much slack leads to inefficiency (Nohria \& Gulati, 1997; Rogers, 2003). Clear priorities and better ability to suspend unsuccessful projects might be beneficial in creating the organizational slack needed.

Our study suggests that, in order to increase opportunities for innovation, management should take more responsibility for improving communication processes narrowing the gap between employees when discussing new ideas, Backström et al. (2006) introduce the metaphor of the middle manager as a director creating the conditions for communication and cooperation. Ibbotson and Darsø (2008, p. 548) describe how leaders may learn from the theatre director where "the art of directing creativity is linked to developing competencies of conscious presence, attention and vigilance, whereas the craft of directing creativity concerns communication, framing and choice." In order to create internal momentum for adaption and innovation, there is also a need to share interpretations of threats and opportunities among organizational members, according to Hoppe (2009).

Autonomy is seen as one of the core elements for EDI alongside commitment, cooperativeness, pride, trustfulness, tolerance, feeling of security, and learning orientation (Amundsen et al., 2011). In addition, Kalmi and Kauhanen (2008) claim that workplace innovations are mainly beneficial for workers. Razulzada (2007) concludes that an innovative climate can positively affect individual wellbeing; as such, a climate demands greater autonomy and more control over the work situation. However, Cowan et al. (2011, p. 165) argue that "high rates of innovation can result in high stress equilibrium and have a negative effect on economic growth."

The studied informants regarded themselves as professionals doing important jobs. Professionalism is important for one's self-esteem and self-image and may be a positive force favoring innovation (Damanpour \& Gopalakrishnan, 1998). We would like to stress that if professionalism becomes too rigid, it may lead to groupthink and to resistance to new ideas and innovation (Rosander et al., 1998), so a delicate balance must be maintained. Resistance to new ideas found in the present study may simply have resulted from a lack of communication, which in turn can be traced back to insufficient organizational slack. It may also indicate groupthink and resistance to new ideas, even among well-educated employees with established professional roles.

The informants described their organizational commitment as high and as a factor that positively affected their desire to improve operations. This finding is in line with that of Shore (1993), who described organizational commitment as a positive factor favoring innovation.

The study also revealed a tension between high commitment to client demands for efficiency and high quality and other organizational demands, such as rigid rules, processes, and assignments. Stream et al. (2011) argue that when means and methods are rigidly specified and are being measured, this may lead to less innovation, as employees are not allowed to implement innovative ideas they believe will serve the client better. This tension leads to an ethical dilemma among employees who must choose between client needs and organizational performance demands. Thunman (2013) claims 
that NPM steering mechanisms cause inauthentic work situations. It might also lead to moral conflicts among the employees and challenge their personal integrity. It should also be noted that the work done, for example, in caring for the elderly, might be complex, as it involves mind, heart, and hands (Kamp \& Hvid, 2012). This work complexity could enter into informant complaints about the lack of understanding from colleagues. It can be argued that good communication between employees and between employees and management in such a context is extremely important if ideas are to be accepted and evolve into innovations.

\section{Support: Leadership and innovation processes}

According to this study, most employees perceive their managers as supportive of new ideas and innovation. However, if previous experiences have been negative and the employee was not listened to, it might be difficult to regard new ideas from colleagues and management in a positive light. Information stickiness, here in the form of a negative view of the opportunities to propose ideas and influence managers, might be difficult to break away from (Hippel, 2006). This may be an important problem for management to address, so work on communication, team climate, and attitudes may be needed.

The organizations studied here all had innovation on their agendas in some way. However, an innovative organization without structure and support to implement innovative ideas may cause stress instead of leading to positive results (Cowan et al., 2011). Birkinshaw and Duke (2013) also point to the fact that EDI requires systematic programs and activities to reinforce the desired behavior, which calls for constant monitoring from the top. In our study, these systematic programs and activities, as well as dialogue with management at all levels, were largely found to be missing. One possible first step toward a working structure is for management to encourage learning about innovation. Management can also facilitate innovation by providing resources such as innovation specialists.

From this study, we found that managers encouraged employees to be innovative, but the employees themselves did not mention the existence of a clear process to help them be innovative and to implement innovations being made. Even if such a process and a system of nurturing ideas existed, none of the informants in our study said they knew of such a system. This indicates the existence of a gap regarding communication and attitudes between the management, responsible for the innovation process, and the employees who were supposed to use it. This gap negatively affected both innovation initiation (i.e., idea development) and implementation, as no decisions on innovation were formally made. It may also highlight the differences between rhetoric and action. Therefore, people working with innovation need to practice and interact in complex processes with others in order to drive innovation processes forward (Darsø, 2012).

When innovative ideas and issues are left to the staff to realize, but without sufficient support, this burdens them, which may cause disappointment and stress in a tight staffing situation. An implementation problem can also arise when innovation is primarily seen as a HR policy and this becomes more important than the actual innovation (Nählinder, 2013). Such tendencies were observed in the present study.

Overall, the studied situation brought to mind the Swedish government's views of innovation and actions to foster it in the public sector, where actual support and financing 
are lacking (Government Offices of Sweden, 2012). Instead, innovation policies and strategies are created for county councils and municipalities to implement on their own. Costs and problems that may be encountered are left for the county councils and municipalities to resolve. The Swedish innovation policy is weak (OECD, 2013), as noted above.

We suggest that innovation should be integrated into the organization, just as quality control systems are, for example. Innovation is an important factor for organizations that truly aim to achieve their organizational goals, especially in combination with learning strategies, as well as being a factor promoting employee wellbeing. An explicitly formulated innovation goal is essential, and organizations must have a strategy that describes in some detail what they want to achieve with it (Mulgan \& Albury, 2003). However, overly complicated systems and too many rules can inhibit ideas, development, and innovation (Daft, 2010). The suggested EDI model based on the results of this study can provide simple guidelines for creating EDI systems for welfare services and the like, where we would like to stress the importance of addressing all three categories at the same time in order to achieve real change in the innovative capability of the organization.

\section{Conclusion}

The study's results showed that development, support, and organizational culture greatly influenced the employee's ability to participate in and contribute to the organization's innovative processes. Within each of these main themes were both opportunities and barriers.

Despite commitment to innovation on the part of both management (as employees described it) and the employees themselves, the lack of support and time (i.e., a lack of productive organizational slack) resulted in a tension between day-to-day work and innovation. The management desire for innovation and change could also create fatigue and stress when this situation was not resolved. Attitudes of colleagues and lack of communication among them were also barriers to implementing innovation, suggesting that it may even be a precondition for EDI that management supports a communicative and open culture. Innovations were also not diffused, as proper innovations systems and processes were lacking

Thus, although some incremental innovations were made, the potential for extensive and genuine EDI in the studied municipalities and units was not fulfilled. Management therefore needs to support the innovation process more actively and to facilitate learning. Employees must be given enough support along with the mandate and sufficient time to implement the ideas that emerge from continuous learning, time for reflection, and dialogue with users.

On the basis of the results, a model was formulated that may help management take advantage of the benefits of EDI. The model incorporates the essential preconditions for employee participation in innovation, attitudes, communication, learning, creativity, innovation processes, and leadership. The model could also be employed to check the status of the organization and to provide the basis for an EDI action plan. Further research could use this model when monitoring EDI processes in welfare services.

Our findings provide insights into how employees themselves understand their participation in the innovation process. Regardless of the fact that the study was performed 
in the context of public welfare services, there is nothing in the study that indicates that the experiences of the employees and the derived model should be unique to this context. Instead, the results appear quite generic, why it will be lucrative to compare these results with EDI practices in both similar and different contexts, thus building a more solid theoretical base for how to improve EDI performance.

\section{References}

Alasoini, T. (2011). Workplace Development as Part of Broad-based Innovation Policy: Exploiting and Exploring Three Types of Knowledge. Nordic Journal of Working Life Studies, 1: 23-43.

Almqvist, R. (2006). New public management - om konkurrensutsättning, kontrakt och kontroll (New public management - on competition, contracts and control), Malmö, Liber.

Alvesson, M. (2003). Beyond Neopositivists, Romantics, and Localists: A Reflexive Approach to Interviews in Organizational Research. The Academy of Management Review, 28, 1: 13-33.

Amundsen, O., Gressgård, L. J., Hansen, K. \& Aasen, T. M. (2011). Medarbeiderdrevet innovasjon-en kunnskapsstatus, Stavanger, International Research Institute of Stavanger.

Arbets- och näringsministeriet (Ministry of Employment and Economy). (2013.) LiideriAffärsverksambet, produktivitet och arbetsglädje (Liideri - Business, productivity and job satisfaction) [Online]. Helsinki: Arbets- och näringsministeriet (Ministry of Employment and Economy). Available: http://www.tyoelama2020.fi/sv/for_arbetsplatserna/stod_och_ hjalp_i_utvecklingen/delta_i_utvecklingsprogram/liideri-programmet [Accessed September 27, 2013].

Australian Government, Department of Education, Employment and Workplace Relations (2009). Australian Public Service Innovation Action Plan, Canberra, Australian Government.

Backström, T., Döös, M. \& Wilhelmson, L. (2006). Chefen som regissör - ledarskap och medarbetarskapets självorganiserande processer. In: Otter, C. (ed.). Ledarskap för fria medarbetare (Leadership for free employees). Stockholm, Arbetslivsinstitutet.

Bason, C. (2010). Leading Public Sector Innovation: Co-creating for a Better Society, Bristol, Policy Press.

Bekkers, V., Edelenbos, J. \& Steijn, B. (2011). Innovation in the Public Sector - Linking capacity and Leadership, Basingstoke, Palgrave-MacMillan.

Birkinshaw, J. and Duke, L. (2013). Empoloyee-led innovation. Business Strategy Review, 2: 46-51.

Brandi, U. and Hasse, C. (2012). Employee-Driven Innovation and Practice-Based Learning in Organizational Cultures. In: Høyrup, S., Hasse, C., Bonnafous-Boucher, M., Møller, K. \& Lotz, M. (eds.) Employee-Driven Innovation A New Approach. Houndmills, Palgrave Macmillan.

Braun, V. and Clarke, V. (2006). Using thematic analysis in psychology. Qualitative Research in Psychology, 3, 2: 77-101.

Chang, S., Gong, Y. and Shum, C. (2011). Promoting innovation in hospitality companies through human resource management practices. International Journal of Hospitality Management, 30, 4: 812-818.

Christensen, T. and Lægreid, P. (2007). Transcending new public management: The transformation of public sector reforms, Burlington, Ashgate.

Cowan, R., Sanditov, B. and Weehuizen, R. (2011). Productivity effects of innovation, stress and social relations. Journal of Economic Behavior \& Organization, 79, 3: 165-182. 
Daft, R. L. (2010). Understanding The Theory and Design of Organizations-Eleventh Edition. Independence, South-Western Cengage Learning.

Damanpour, F. and Gopalakrishnan, S. (1998). Theories of organizational structure and innovation adoption: the role of environmental change. Journal of Engineering and Technology Management, 15, 1: 1-24.

Danish Government (2006). Fremgang, fornyelse og tryghed - strategi for Danmark i den globale økonomi (Success, renewal and security - Strategy for Denmark in the globale economy). Copenhagen, Danish Government.

Danske LO (Danish Confederation of Trade Unions) (2008). Employee-driven innovation Improving economic performance and job satisfaction. Copenhagen, Danske LO.

Darsø, L. (2012). Innovation Competency - An Essential Organizational Asset. In: Høyrup, S., Hasse, C., Bonnafous-Boucher, M., Møller, K. and Lotz, M. (eds.) Employee-Driven Innovation A New Approach. Houndmills, Palgrave Macmillan.

Davila, T., Epstein, M. and Shelton, R. (2005). The Art of Innovation, Philadelphia, PA, Wharon School Publishing.

Earl, L. (2002). Innovation and Change in the Public Sector: A Seeming Oxymoron, Toronto, Statistics Canada.

Ellström, P.-E. (2005). Arbetsplatslärandets janusansikte. Pedagogisk Forskning i Sverige, 10, 3/4: 182-194.

Ellström, P.-E. (2010). Practice-based innovation: a learning perspective. Journal of Workplace Learning, 22, 1/2: 27-40.

Eurobarometer (2011). Innobarometer 2010 Analytical Report Innobarometer: Public Administration. Brussels, European Commission.

Eurobarometer (2012). Innovation in the Public Sector: Its perception in and impact on business. Brussels, European Commission.

Evans K, Hodkinson P, Rainbird H, and Unwin L (2006) Improving Workplace Learning. London and New York: Routledge.

Fogelberg Eriksson, A., Aasen, T. M. and Møller, K. Nordiske strategier for medarbeiderdrevet innovasjon Arbeidsseminar om medarbeiderdrevet innovasjon (MDI) i Norden, 2013. Norden.

Fonseca, J. (2004). Complexity and innovation in organizations, London, Routledge.

Forskningsrådet (The Norwegian Research Council). (2012). RE: Innovasjon $i$ offentlig sektor: Policy for Forskningsradets arbeid (Innovation in the public sector: Policy for the work of the council). Oslo, Forskningsrådet.

Government Offices of Sweden (2012). The Swedish Innovation Strategy, Stockholm, Government Offices of Sweden.

Guba, E. G. (1981). Criteria for Assessing the Trustworthiness of Naturalistic Inquiries. ERIC/ECTJ Annual Review Paper, 29, 2: 75-91.

Hartley, J. (2005). Innovation in Governance and Public Services : Past and Present. Public Money \& Management, 25, January: 27-35.

Hartman, L. (2011). Konkurrensens konsekvenser: Vad händer med svensk välfärd (Consequences of competition: What happens to the Swedish welfare), Stockholm, SNS förlag.

Hasselbladh, H., Bejerot, E. and Gustafsson, R. Å. (2008). Bortom New Public Management: Institutionell transformation i svensk sjukvard (Beyond New Public Management: Institutional transformation in Swedish healthcare), Lund, Academia adacta.

Hippel, E. (2006). Democratizing Innovation, London, MIT Press.

Holman, D., Totterdell, P., Axtell, C., Stride, C., Port, R., Svensson, R. and Zibarras, L. (2012). Job Design and the Employee Innovation Process: The Mediating Role of Learning Strategies. Journal of Business and Psychology, 27, 2: 177-191.

Hoppe, M. (2009). Myten om det rationella flödet. PhD Thesis, Åbo, Åbo Akademi. 
Hovlin, K., Arvidsson, S., Hjort, M. and Ljung, A. (2011). Tjänsteinnovationer $i$ offentlig sektor, Stockholm, Vinnova.

Høyrup, S. (2012). Employee-driven innovation: A New Phenomenon, Concept and Mode of Innovation. In: Høyrup, S., Hasse, C., Bonnafous-Boucher, M., Møller, K. and Lotz, M. (eds.) Employee-Driven Innovation A New Approach. Houndmills, Palgrave Macmillan.

Ibbotson, P. and Darsø, L. (2008). Directing creativity: The art and craft of creative leadership. Journal of Management and Organization, 14, 5: 548-559.

IVA and Sifo (2010). Svenska folkets kunskap och attityd kring innovation (Swedish people's knowledge and attitudes about innovation). Stockholm, IVA.

Jalonen, H. (2011). Enabling Innovation in Complex Welfare Service Systems. Journal of Service Science and Management, 04, 401-418.

Kallstenius, J. (2010). De mångkulturella innerstadsskolorna: Om skolval, segregation och utbildningsstrategier i Stockholm. PhD thesis, Stockholm, Stockholm University.

Kalmi, P. and Kauhanen, A. (2008). Workplace Innovations and Employee Outcomes: Evidence from Finland. Industrial Relations, 47, 3: 430-459.

Kamp, A. and Hvid, H. S. (2012). Elderly care in transition: Management, meaning and identity in work, Copenhagen, Copenhagen Business School Press.

Karasek, R. and Theorell, T. (1990). Healthy work: Stress, productivity, and the reconstruction of working life, New York and N.Y, Basic Books

Kesting, P. and Ulhøi, J. P. (2010). Employee-driven innovation: extending the license to foster innovation. Management Decision, 48, 1: 65-84.

King, E. B., Chermont, K., West, M., Dawson, J. F. and Hebl, M. R. (2007). How innovation can alleviate negative consequences of demanding work contexts: The influence of climate for innovation on organizational outcomes. Journal of Occupational and Organizational Psychology, 80, 4: 631-645.

Klitmøller, A., Lauring, J. \& Rind Christensen, P. (2007). Medarbejderdreven innovation i den offentlige sektor (Employee-driven innovation in the public sector). Ledelse \& Erhvervsøkonomi, 71, 4: 207-216.

Kristiansen, M. and Bloch-Poulsen, J. (2010). Employee Driven Innovation in Team (EDIT) Innovative Potential, Dialogue, and Dissensus. International Journal of Action Research, 6, 2/3: 155 .

Kvale, S. and Brinkmann, S. (2009). Den kvalitativa forskningsintervjun, Lund, Studentlitteratur $\mathrm{AB}$.

Langergaard, L. L. and Hansen, A. V. Innovation - a one size fits all concept? The XXIV ISPIM Conference 2013 Helsinki. ISPIM.

Lewins, A. and Silver, C. (2006). Choosing a CAQDAS Package, Project, Guldford, Univeristy of Surrey.

Lindell, M. and Arvonen, J. (1996). The Nordic management style in a European context. International Studies of Management \& Organization, 26, 3: 73.

Lämsa, T. (2010). Leadership styles and decision-making in Finnish and Swedish organizations. Review of International Comparative Management, 11, 8: 139-149.

Martins, E. C. \& Terblanche, F. (2003). Building organisational culture that stimulates creativity and innovation. European Journal of Innovation Management, 6, 1: 64-74.

Maxqda (2013). A professional tool for Qualitative Data Analysis. Berlin, Verbi.

May, K. A. (1991). Interview techniques in qualitative research: Concerns and challenges. Thousand Oaks, Sage Publications.

Meyer, J. P. \& Allen, N. J. (1991). A three-component conceptualization of organizational commitment. Human Resource Management Review, 1, 1: 61-89.

Mindlab (2012). Fra indsigt til forandring: MindLabs Resultatsrapport 2011-12 (From insight to change: Mindlab Report 2011-12), København. 
Miner, A. S., Bassof, P. \& Moorman, C. (2001). Organizational improvisation and learning: A field study. Administrative Science Quarterly, 46, 2: 304-337.

Mulgan, G. (2007). Ready or not? Taking innovation in the public sector seriously, London, Nesta.

Mulgan, G. \& Albury, D. (2003). Innovation in the public sector. London, U.K. Government.

Nesta andInnovation Unit (2012). Getting ready for radical efficiency, London, Nesta.

Nilsen, P. and Ellström, P.-E. (2012). Fostering Practice-Based Innovation Through Reflection at Work: In: Melkas, H. and Harmaakorpi, V. (eds.). Practice-Based Innovation: Insights, Applications and Policy Implications. Berlin, Springer.

Nilsen, P., Nordström, G. \& Ellström, P.-E. (2012). Integrating research-based and practice-based knowledge through workplace reflection. Journal of Workplace Learning, 24, 6: 403-415.

Nohria, N. \& Gulati, R. (1997). What is the Optimum Amount of Organizational Slack? A Study of the Relationship between Slack and Innovation in. European Management Journal, 15, 6: 603-611.

Nyström, M. E. (2010). Chefsuppdragets komplexitet i politiskt styrda organisationer, Stockholm, Karolinska Institutet.

Nählinder, J. (2013). Understanding Innovation in a Municipal Context: a Conceptual Discussion. Innovation: Management, policy \& practice, 15, 4: 315-325.

Nærings- og handelsdepartementet (Ministry of Business and Trade) (2008). Et nyskapende og bærekraftig Norge (An innovative and sustainable Norway), Oslo, Nærings- og handelsdepartementet.

OECD (2013). OECD Reviews of Innovation Policy: Sweden 2012. Paris, OECD Publishing.

Parent-Thirion, A., Fernández Macías, E., Hurley, J. \& Vermeylen, G. (2007). Fourth European working conditions survey. Dublin, European foundation for the improvement of living and working conditions.

Rasulzada, F. (2007). Organizational creativity and psychological well-being - contextual aspects on organizational creativity and psychological well-being from an open systems perspective. PhD thesis, Lund, Lund university.

Regeringen (Government Offices of Sweden) (1976). Lag 1976: 580 om medbestämmande i arbetslivet (Act 1976: 580 concerning participation in working life), Stockholm, Regeringen (Government Offices of Sweden).

Regeringen (Government of Sweden) (1993). Regeringens Proposition 1992/93: 230 Valfrihet i skolan (The Government Bill 1992/93: 230 Freedom of Choice in schools), Stockholm, Regeringen (Government of Sweden).

Rittel, H. W. J. \& Webber, M. M. (1973). Dilemmas in a general theory of planning. Policy Sciences, 4, 2: 155-169.

Rogers, E. M. (2003). Diffusion of Innovation, 5th ed, New York, Free Press.

Rosander, M., Stiwne, D. \& Granström, K. (1998). Bipolar groupthink: assessing groupthink tendencies in authentic work groups. Scandinavian journal of psychology, 39, 2: 81-92.

Smith, P., Ulhöi, J. P. \& Kesting, P. (2012). Mapping key antecedents of employee-driven innovations. Int. J. Human Resources Development and Management, 12, 3: 224-236.

Smith, P. B., Andersen, J. A., Ekelund, B., Graversen, G. \& Ropo, A. (2003). In search of Nordic management styles. Scandinavian Journal of Management, 19, 4: 491-507.

Socialdepartementet (Ministry of Health and Social Affairs) (2011). Uppdrag angående social innovation $\mathrm{i}$ vården och omsorgen om de mest sjuka äldre samt utbetalning av medel (Assignments on social innovation in health and social care for the elderly most ill and distribution of funds), Stockholm, Regeringskansliet.

Stacey, R. D. (2003). Strategic management and organizational dynamics: The challenge of complexity, New York, Financial Times. 
Stream, C., Word, J., Lukasiak, K. \& Affairs, P. (2011). What Cannot Be Counted. Ethics, Innovation, and Evaluation in the Delivery of Public Services, 16, 2.

Thunman, E. (2013). Inauthenticity at Work: Moral Conflicts in Market- oriented Welfare Organizations. Nordic journal of working life studies Volume, 3, 2: 37-57.

Tidd, J. \& Bressant, J. (2009). Managing innovation, Andover, John Wiley \& Sons.

Vetenskapsrådet (Swedish Research Council) (2012). Ethical guidelines for Humanities and Social sciences, Stockholm, Vetenskapsrådet.

West, M. A. \& Farr, J. L. (1990). Innovation and Creativity at Work: Psychological and Organizational Strategies, Hoboken, John Wiley \& Sons.

Åmo, B. W. (2006). Employee innovation behaviour in health care: the influence from management and colleagues. International nursing review, 53, 3: 231-237. 